\title{
A Small Collection of Leucosiid Crabs (Crustacea: Decapoda: Brachyura) from Balicasag Island, Bohol, Philippines
}

\author{
Hironori Komatsu ${ }^{1}$, Marivene R. Manuel $^{2}$ and Masatsune Takeda ${ }^{1}$ \\ ${ }^{1}$ Department of Zoology, National Science Museum, \\ 3-23-1 Hyakunin-cho, Shinjuku-ku, Tokyo, 169-0073 Japan \\ Present address of HK: Fisheries Research Section, \\ Hokkaido Nuclear Energy Environmental Research Center, \\ 261-1 Miyaoka, Kyowa, Iwanai, Hokkaido, 045-0123 Japan \\ E-mail: komatsu.hironori@pref.hokkaido.jp (HK) \\ E-mail: takeda@kahaku.go.jp (MT) \\ ${ }^{2}$ Zoology Division, National Museum, \\ P. Burgos St., P.O. Box 2659, Manila 1000, Philippines \\ E-mail:vinrmanuel@yahoo.com (MRM)
}

(Received 5 July 2004; Accepted 22 March 2005)

\begin{abstract}
A small collection of leucosiid crabs collected by tangle nets from Balicasag Island, Bohol, Philippines, includes a total of 28 species belonging to 16 genera. Of these, two new species, Raylilia intermedia and Tokoyo trilobata, are described, and the following six species are recorded as new to the Philippines: Arcania muricata Galil, 2001, Drachiella angulata (Ihle, 1918), Leucosia anatum (Herbst, 1783), Merocryptus lambriformis A. Milne-Edwards, 1873, Myra grandis Zarenkov, 1990, and Tanaoa yokoyai (Sakai, 1965), n. comb.
\end{abstract}

Key Words: Crustacea, Decapoda, Leucosiidae, new species, Balicasag, Philippines.

\section{Introduction}

In February, 2003, an opportunity arose to make a field trip to Balicasag Island, Bohol, Philippines, as a part of the research project of the National Science Museum, Tokyo, entitled "Natural History Researches of the Island Arcs in the Western Pacific". On this trip, a small collection of crabs of the family Leucosiidae Samouelle, 1819 made by local shell fishermen of Balicasag Island, using tangle nets was obtained. In addition to this material, crabs collected from depths of 80-150 m off Balicasag Island on 6-10 March 1999 were examined through the kind cooperation of Dr. Tomoki Kase of the National Science Museum, Tokyo. As a comparative material, the specimens of Raylilia mirabilis (Zarenkov, 1969) collected from Japanese waters were also examined. The collections include a total of 28 species belonging to 16 genera (Table 1). Some of the species are rare and worthy of note. In this paper, two new species are described and six species are recorded as new to the Philippines.

Measurements, given in millimeters $(\mathrm{mm})$ and expressed in parentheses as length $\times$ breadth, are of the greatest carapace length and breadth (including the marginal spines), respectively. Pereiopods are measured along their outer margin 
Table 1. List of the leucosiid crabs collected from Balicasag Island, Bohol, Philippines.

\begin{tabular}{|c|c|c|}
\hline Species name & $\begin{array}{l}\text { Specimens at NSMT } \\
\text { (Registration no.) }\end{array}$ & $\begin{array}{l}\text { Specimens at NMCR } \\
\text { (Registration no.) }\end{array}$ \\
\hline Arcania cornuta (MacGilchrist, 1905) & $1 \delta(15791)$ & \\
\hline *Arcania muricata Galil, 2001 & $3 ð ઠ َ, 19(15792)$ & $6 ð ð, 2 q q(13510)$ \\
\hline Arcania gracilis Henderson, 1893 & $1 q(15793)$ & \\
\hline Arcania undecimspinosa De Haan, 1841 & $4 ठ ゚ す, 2 \subsetneq \subsetneq(15794)$ & 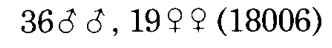 \\
\hline *Drachiella angulata (Ihle, 1918) & $2 q q(15795)$ & \\
\hline Ebalia scabriuscula Ortmann, 1892 & $1 q(15796)$ & \\
\hline Euclosia crosnieri (Chen, 1989) & $2 \delta^{\star}, 2 q q(15797)$ & $7 \delta す, 6 ㅇ ㅜ(18003)$ \\
\hline Euclosia scitula Galil, 2003 & $4 \delta す, 4 q$ (15798) & $11 \delta す, 7 q q(18001)$ \\
\hline Euclosia unidentata (De Haan, 1841) & $1 ठ(15799)$ & $1 \delta(18004)$ \\
\hline Heteronucia laminata (Doflein, 1904) & $20 \hat{\sigma}, 19(15800)$ & $2 q q(18014)$ \\
\hline Ixa pulcherrima (Haswell, 1880) & $2 q q(15801)$ & \\
\hline *Leucosia anatum (Herbst, 1783) & $3 ठ ð(15802)$ & $13 \delta す, 3 q q(18000)$ \\
\hline *Merocryptus lambriformis & $1(15803)$ & \\
\hline A. Milne-Edwards, 1873 & & \\
\hline Myra biconica Ihle, 1918 & $20 \hat{\sigma}, 6 q q(15804)$ & $31 ठ ઼, 4$ ㅇํ (18008) \\
\hline Myra curtimana Galil, 2001 & $5 \delta \delta, 2 \uparrow q(15805)$ & $8 \delta \delta, 6 q q(13509)$ \\
\hline Myra eudactyla (Bell, 1855) & $1 q(15806)$ & $1 \delta(13510)$ \\
\hline *Myra grandis Zarenkov, 1990 & $1 \delta, 2 ㅇ(15807)$ & 30 ठे, $11 \% q(18007)$ \\
\hline Parilia major Sakai, 1961 & $1 \delta, 1 q(15808)$ & 30 ઠ, 11 ㅇ $(18005)$ \\
\hline Parilia ovata Chen, 1984 & $1+(15809)$ & $1 ð(13511)$ \\
\hline Pariphiculus agariciferus Ihle, 1918 & $1 \delta, 1 q(15810)$ & \\
\hline $\begin{array}{l}\text { Pariphiculus coronatus } \\
\text { (Alcock and Anderson, 1894) }\end{array}$ & $1 \delta, 3 q q(15811)$ & $1 \delta, 8 q q(18013)$ \\
\hline Praebebalia septemspinosa Sakai, 1983 & $3 ठ \delta, 2 \uparrow q(15812)$ & $1 \delta, 19(18016)$ \\
\hline *Raylilia intermedia $\mathrm{n} . \mathrm{sp}$ & $\begin{array}{l}10 \text { (holotype, } 15813 \text { ); } \\
1 \text { ㅇ (paratype, 15814) }\end{array}$ & \\
\hline Tanaoa pustulosa (Wood-Mason, 1891) & $1 \delta, 1 q(15815)$ & $5 \delta \delta, 1 q(18012)$ \\
\hline *Tanaoa yokoyai (Sakai, 1965) & $1 \delta(15816)$ & \\
\hline Tokoyo eburnea (Alcock, 1896) & $\begin{array}{l}1 \delta, 1 \uparrow(15817) \\
1 \delta^{\star}, 1 \uparrow(15821)\end{array}$ & 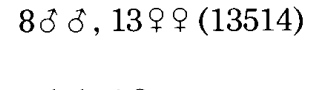 \\
\hline *Tokoyo trilobata $\mathrm{n} . \mathrm{sp}$. & $\begin{array}{l}1{ }^{\star} \text { (holotype, 15818); } \\
2 \delta^{\star}, 2 \text { } 2 \text { (paratypes, 15819) }\end{array}$ & $\begin{array}{l}3 \delta \delta, 19 \\
\text { (paratypes, 18009) }\end{array}$ \\
\hline Urashima pustuloides (Sakai, 1961) & $1 \delta, 1 q(15820)$ & $2 \delta^{0}, 2 q 9(18011)$ \\
\hline
\end{tabular}

* First records for the Philippines.

from ischium to dactylus. The specimens examined are deposited in the National Science Museum, Tokyo (NSMT), the National Museum of the Philippines (NMCR), and the Natural History Museum and Institute, Chiba (CBM).

\section{Taxonomy}

Arcania muricata Galil, 2001

(Fig. 1A)

Arcania muricata Galil, 2001b: 189, figs 2E, 6B. 
Material examined. NSMT-Cr 15792, 30 o $(19.9 \times 17.8-23.4 \times 19.4), 1$ ovig. (24.0×20.8), Feb. 2003; NMCR 13510, 6 우, 2 우 $(22.5 \times 22.0-27.5 \times 24.0)$, Feb. 2003.

Remarks. This is the first record for the Philippines. The present specimens agree with the original description except shape of the lateral spines of carapace, which is simple in the present specimens (curved forwards in the original description). But this difference can be considered as an interspecific variation, because


Fig. 1. Leucosiid crabs from Balicasag Island, Bohol, Philippines (specimens in alcohol). A, Arcania muricata Galil, 2001, o (23.4×19.4), NSMT-Cr 15792; B, Drachiella angulata (Ihle, 1918 ), $q$ (14.9×18.5), NSMT-Cr 15795; C, Leucosia anatum (Herbst, 1783), o $(24.0 \times 19.8)$, NSMTCr 15802; D, Merocryptus lambriformis A. Milne-Edwards, 1873, q (12.6×13.4), NSMT-Cr 15803; E, Myra grandis Zarenkov, 1990, of (27.6×21.9), NSMT-Cr 15807; F, Tanaoa yokoyai (Sakai, 1965), o (14.8×11.1), NSMT.Cr 15816. 
the shape of the male first pleopod agrees well with the original description and figure. This species can be easily distinguished from its congeners by the bright red, veiny pattern on the upper surface of carapace, which is seen even in preserved specimens in spirit.

Distribution. Vietnam, Philippines, Arafura Sea (type locality), Australia. All the localities were recorded by Galil (2001b) except Philippines (present study). Occurring at depths of $27-38 \mathrm{~m}$.

\section{Drachiella angulata (Thle, 1918)}

(Fig. 1B)

Actaeomorpha aglypha var. angulata Ihle, 1918: 209, fig. 120.

Oreophorus (Oreophorus) aglyphus ihlei Takeda, 1977: 120. [New name for Actaeomorpha aglypha var. angulata Ihle, 1918 preoccupied by Oreophorus (O.) angulatus (Rathbun, 1906)]

Drachiella angulata: Takeda and Tachikawa 1995: 216.

Material examined. NSMT-Cr 15795, 1 ovig. $q(12.9 \times 16.6), 1$ $9(14.9 \times 18.5)$, Mar. 1999.

Remarks. This is the first record for the Philippines and also the first female specimens known for this species. The present specimens are much larger than the holotype male $(5.5 \times 6.5 \mathrm{~mm})$, but otherwise agree well with the original description.

Distribution. Japan (Takeda and Tachikawa 1995), Philippines (present study), Indonesia (type locality; Ihle 1918). Occurring at depths of 9-36 m.

\section{Leucosia anatum (Herbst, 1783)}

(Fig. 1C)

Cancer anatum Herbst, 1783: 93.

Leucosia anatum: Sakai 1976: 116, figs 64, 65a, pl. 34 (1-3).

Material examined. NSMT-Cr 15802, 3ठ 0 (22.0×13.3-24.0×19.8), Feb. 2003; NMCR 18000, 13 むે, 3ㅇ $(22.5 \times 18.0-24.5 \times 19.5)$, Feb. 2003.

Remarks. This is the first record for the Philippines. According to TyndaleBiscoe and George (1962), Leucosia anatum has four color pattern morphs, with the holotype exhibiting Morph A. All the specimens from Balicasag Island have white blotches surrounded by reddish brown lines, thus exhibiting Morph $\mathrm{C}$, which is the most widely distributed of the four, occurring throughout the Indo-West Pacific. Sakai (1976) provides a complete synonymy and distribution.

Distribution. Japan, Korea, China, Taiwan, Philippines, Indonesia (type locality), Thailand, Australia, New Caledonia, India, Sri Lanka, Persian Gulf. Occurring at depths of $10-80 \mathrm{~m}$. 
Merocryptus lambriformis A. Milne-Edwards, 1873

(Fig. 1D)

Merocryptus lambriformis A. Milne-Edwards, 1873: 85, pl. 2 (1); Miers 1886: 320; Whitelegge 1900: 162; Balss 1922: 126; Rathbun 1923: 133, pl. 32 (2, 3); Hale 1927: 201, fig. 202; Sakai 1937: 113, pl. 13 (7), 1965: 30, pl. 14 (1, 2), fig. 3c, 1976: 78, pl. 25 (4), fig. 40c; Bennett 1964: 22, fig. 108; Dell 1968: 13, pl. 1; Takeda and Miyake 1970: 214, 1972: 73; Kim 1973: 294, pl. 76 (59), fig. 90; Dai and Yang 1991: 64, fig. 29, pl. 6 (8); Chen and Sun 2002: 271, fig. 117.

Ebalia rugosa Yokoya, 1933: 124, fig. 43.

Material examined. NSMT-Cr 15803, 1 q $(12.6 \times 13.4$; carapace partially covered with bryozoans and meri of both chelipeds bearing serpulid annelids attached), Feb. 2003.

Remarks. The present specimen agrees with the original description and other records in most of the diagnostic characters, but differs from them in that the branchial process is poorly developed, not exceeding the unarmed epibranchial margin. In more typical specimens, the branchial process is strongly developed and exceeds the branchial margin, which is armed with two small teeth even in females. These discrepancies may be attributed to senility of the present specimen.

Distribution. Japan (Balss 1922; Yokoya 1933; Sakai 1937, 1965, 1976; Takeda and Miyake 1970, 1972; Chen and Sun 2002), Korea (Kim 1973), China (Dai and Yang 1991; Chen and Sun 2002), Philippines (present study), Western Samoa (type locality; A. Milne-Edwards 1873), Australia (Miers 1886; Whitelegge 1900; Rathbun 1923; Hale 1927), New Zealand (Bennett 1964; Dell 1968). Occurring at depths of 40-274 m.

Myra grandis Zarenkov, 1990

(Figs $1 \mathrm{E}, 2 \mathrm{a}-\mathrm{c}$ )

Myra grandis Zarenkov, 1990: 65, pl. 6 (8-12); Galil 2001c: 429, figs 2d, 13.

Material examined. NSMT-Cr $15807, \quad 10^{\star} \quad(27.6 \times 21.9), 29+\quad(37.2 \times 29.6$, 39.4×32.2), Feb. 2003; NMCR 18007, 30 क o , 11 ㅇ $(33.0 \times 20.5-43.0 \times 31.0)$, Feb. 2003.

Remarks. The present specimens agree with the descriptions of Zarenkov (1990) and Galil (2001c) in general morphology except for the male first pleopod. That of the present specimen (NSMT-Cr 15807) is entirely fringed with short, plumose setae along the mesial margin (Fig. 2a), whereas that of Galil (2001c, fig. 13 ) is not depicted with setae along mesial margin.

Distribution. Marquesas Is. (Galil 2001c), Philippines (present study), Kenya (type locality; Zarenkov 1990), Madagascar (Galil 2001c). Occurring at depths of 49-302 m.

Raylilia intermedia $\mathrm{n} . \mathrm{sp}$. 

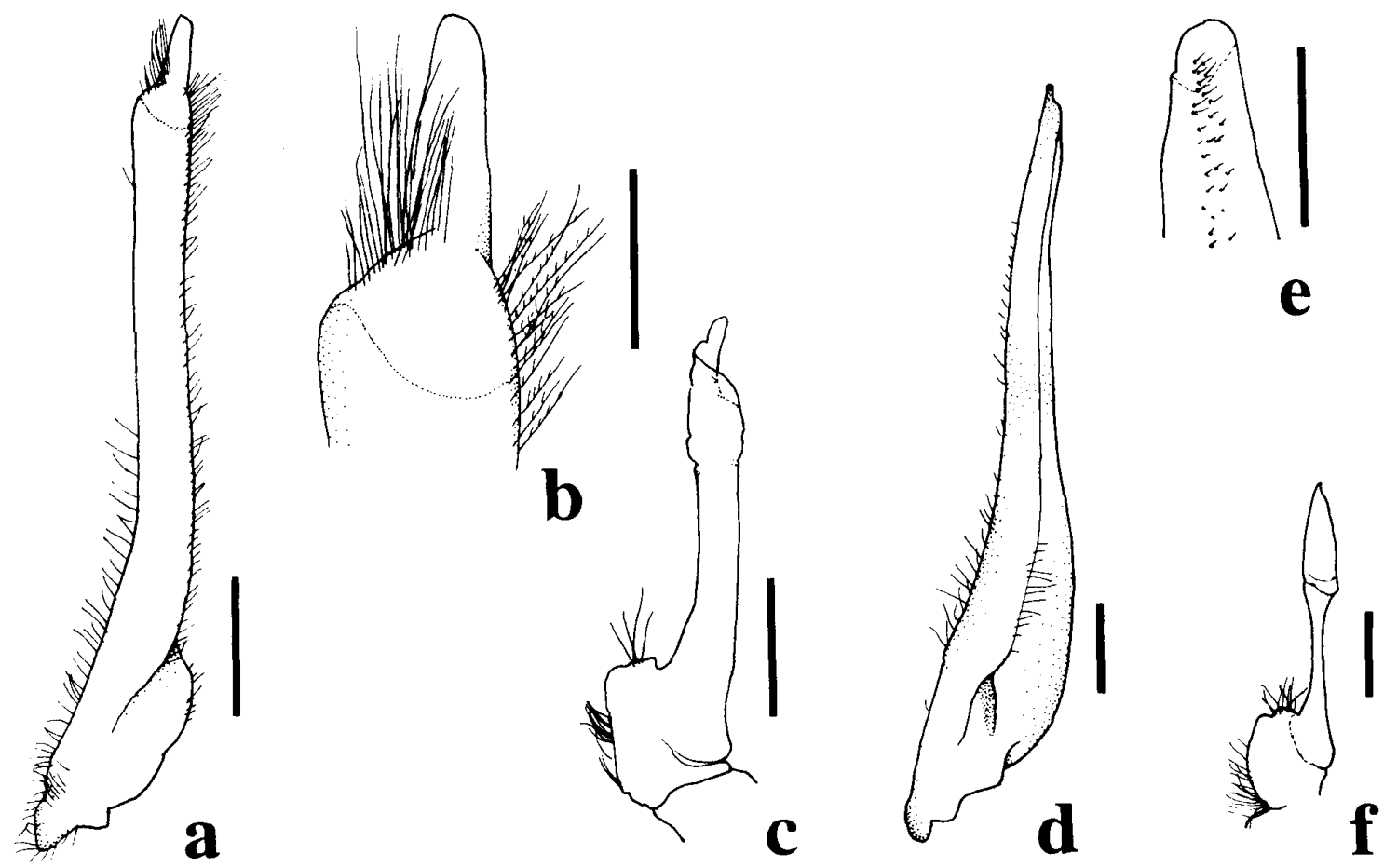

Fig. 2. Myra grandis Zarenokv, 1990, ठ (27.6×21.9), NSMT-Cr 15807 (a-c) and Tanaoa yokoyai (Sakai, 1965), ơ (14.8×11.1), NSMT-Cr 15816 (d-f). a, d, Right first pleopods, external view; b, e, distal parts of same, external view; c, f, male second pleopods, external view. Scales: $2 \mathrm{~mm}$ for a; $1 \mathrm{~mm}$ for $\mathrm{b}, \mathrm{c}, \mathrm{d}, \mathrm{f} ; 0.5 \mathrm{~mm}$ for $\mathrm{e}$.

(Figs 3, 4, 8A, B)

Type series. Holotype: NSMT-Cr 15813, o (9.7 $\times 9.0$; all pereiopods lost except for coxae), Feb. 2003. Paratype: NSMT-Cr 15814, ovig. + (13.0 $\times 13.7$; chelipeds lost), Feb. 2003.

Comparative material examined. Raylilia mirabilis: $10^{\dagger}(6.0 \times 6.1), 1$ q (7.6 $\times 7.7), 26^{\circ} 14.50^{\prime} \mathrm{N}, 127^{\circ} 32.20^{\prime} \mathrm{E}$, south of Amuro-jima I., Kerama Is., Ryukyus, southern Japan, TRV Toyoshio-Maru, cruise TY 98-4 stn 7, dredge, $52 \mathrm{~m}$, sand, coll. T. Komai, 19 May 1998, CBM-ZC 7895; 10 (7.2×7.0; empty shell), 1 \% $(10.5 \times 10.7$; empty shell), $26^{\circ} 14.40^{\prime} \mathrm{N}, 127^{\circ} 21.50^{\prime} \mathrm{E}$, north of Tokashiki-jima I., Ryukyus, southern Japan, TRV Toyoshio-Maru, cruise TY 00-05 stn 12, dredge, $89 \mathrm{~m}$, sand, coll. H. Komatsu, 28 May 2000, NSMT-Cr 15995; $10^{\circ}\left(7.3 \times 7.6\right.$; empty shell), $28^{\circ} 52.14^{\prime} \mathrm{N}$, $129^{\circ} 32.99^{\prime} \mathrm{E}$, Oshima-shinsone Bank, Amami Group, southern Japan, TRV Toyoshio-Maru, cruise TY 03-05 stn 15, dredge, 163-167 m, bed of Porifera and Octocorallia, coll. H. Komatsu, 27 May 2003, NSMT-Cr 15996; 3 우 $(9.4 \times 9.5-10.1 \times 10.5)$, $26^{\circ} 15.34^{\prime} \mathrm{N}, 127^{\circ} 15.96^{\prime} \mathrm{E}$, off Tokashiki-jima I., Kerama Is., Ryukyus, southern Japan, RV Tansei-Maru, cruise KT 02-03 stn E6, dredge, 55-95 m, coll. T. Komai, 19 Apr. 2002, CBM-ZC 7896.

Description. Carapace (Figs 3a, 8A, B) pyriform in general outline, convex dorsally, 1.1 times longer than broad in holotype male, 1.1 times broader than long in paratype ovigerous female; upper surface coarsely covered with vesicular granules. Frontal region strongly produced, medially concave; margin divided into 2 
lobes by small median notch. Orbit with 2 straight fissures on dorsal roof, with broadly $\mathrm{V}$-shaped notch on infraorbital margin; margin entirely fringed with relatively long setae. Mesogastric region strongly protuberant longitudinally; metagastric region with pair of erect, conical tubercles. Cardiac region with erect, conical tubercle equal to gastric one in size. Intestinal region convex, directed dorso-posteriorly, divided by shallow, H-shaped groove, with small subapical tubercle. Hepatic region shallowly concave mesially; margin rectangularly convex, forming right angle with epibranchial margin; hepatic facet developed. Pterygostomian margin rectangularly convex, with tongue-shaped, downwardly directed tubercle on corner. Branchial region with 2 pairs of conical tubercles; anterior tubercle directed antero-laterally, somewhat smaller than gastric one; posterior tubercle directed somewhat postero-laterally, equal to gastric one in size. Epibranchial margin roundly convex, with 3 tubercles; anterior tubercle inconspicuous; posterior 2 tubercles equal in size, small, triangular. Metabranchial margin with 2 conical tubercles; anterior tubercle directed laterally, equal to gastric one in size; posterior tubercle directed postero-laterally, slightly larger than gastric one. Posterior margin with 3 triangular tubercles; median tubercle slightly smaller than lateral ones.

Ocular peduncle (Fig. 3b) short, completely set in orbit when retracted; dorsal extension onto cornea short, subrectangular with rounded tip. Antennule obliquely folded into fossa; basal segment almost covering antennual fossa, covered with microscopic granules. Antenna with transversely ovate basal segment; second segment subsquamate, loosely folded in orbital hiatus. Afferent channel with V-shaped notch at mesial 0.3 and straight fissure at lateral 0.4 of anterior margin; mesial margin with small anterior tooth.

Mandible (Fig. 4a, b) well calcified, transversely short; cutting edge triangular in outline, pointed medially; endopod palp 3-segmented, fringed with short, stout setae on distal portion of second segment and outer margin of terminal segment. Maxillule (Fig. 4c) with coxal endite somewhat compressed, directed mesially, bearing some thin subterminal and stout terminal setae; basial endite triangular, with both stout and thin setae on mesial margin, fringed with some thin setae on lateral margin; endopod triangular, with tip narrowed. Maxilla (Fig. 4d) with coxal endite roundly bilobed; basial endite elongate tongue-shaped, with some terminal setae; endopod triangular, constricted at tip; exopod (scaphognathite) longitudinally expanded into oval structure, entirely fringed with short, plumose setae. First maxilliped (Fig. 4e) with coxal endite semiglobular, bearing dense setae; basial endite lobular, tongue-shaped, densely fringed with moderately long, plumose setae along entire margin; endopod lobular, longitudinally expanded, rounded at apex, fitting into efferent channel, fringed with short, plumose setae along lateral margin of apex; exopod longitudinally filiform, with small triangular process on distal 0.2 of lateral margin, some moderately long, plumose setae around tip, and flagellum bearing some moderately long terminal setae. Second maxilliped (Fig. 4f) with fringe of long setae along mesial margin of ischium and merus; propodus fringed with setae along outer and distal margin; dactylus armed with stout setae around tip; exopod filiform, tapering distally, fringed with long, plumose setae along distal 0.2 of mesial margin, bearing flagellum with some terminal setae; exite auriculiform.

Third maxilliped (Fig. 4g, h) covered with vesicular granules of various sizes; basis fused with ischium, but with remnant suture on internal surface; ischium 

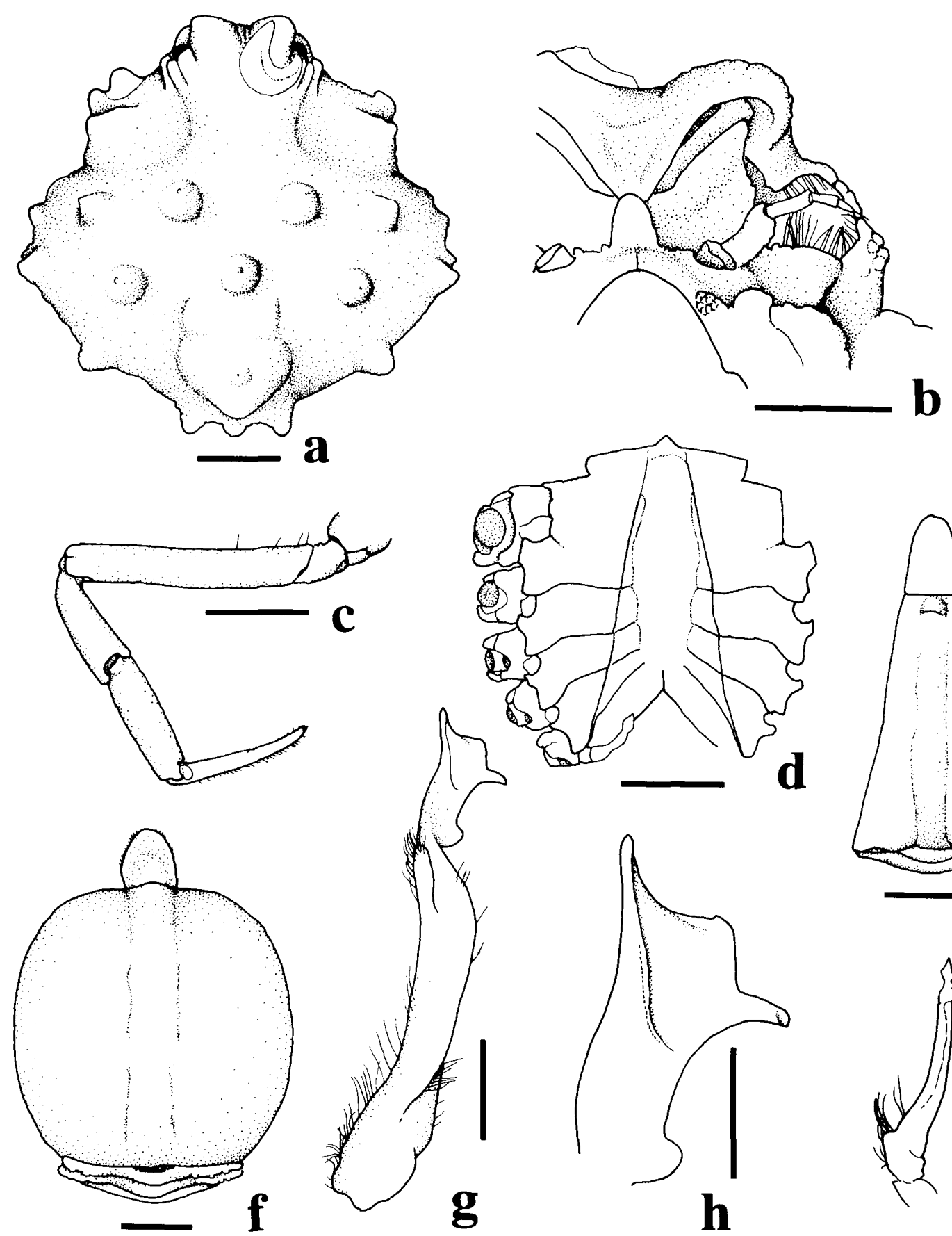

Fig. 3. Raylilia intermedia n. sp., holotype, $\$(9.7 \times 9.0)$, NSMT-Cr 15813 (a, b, d, e, g-i) and paratype, ovig. 9 (13.0 $\times 13.7)$, NSMT-Cr 15814 (c, f). a, Carapace, dorsal view; b, frontal region, ventral view; c, left fourth ambulatory leg, dorsal view; d, male thoracic sternites, ventral view; e, male abdomen, ventral view; f, female abdomen, ventral view; g, male first pleopod, external view; h, distal part of same, external view; i, male second pleopod, external view. Scales: $2 \mathrm{~mm}$ for a, c-f; $1 \mathrm{~mm}$ for $\mathrm{b}, \mathrm{g}, \mathrm{i} ; 0.5 \mathrm{~mm}$ for $\mathrm{h}$. 

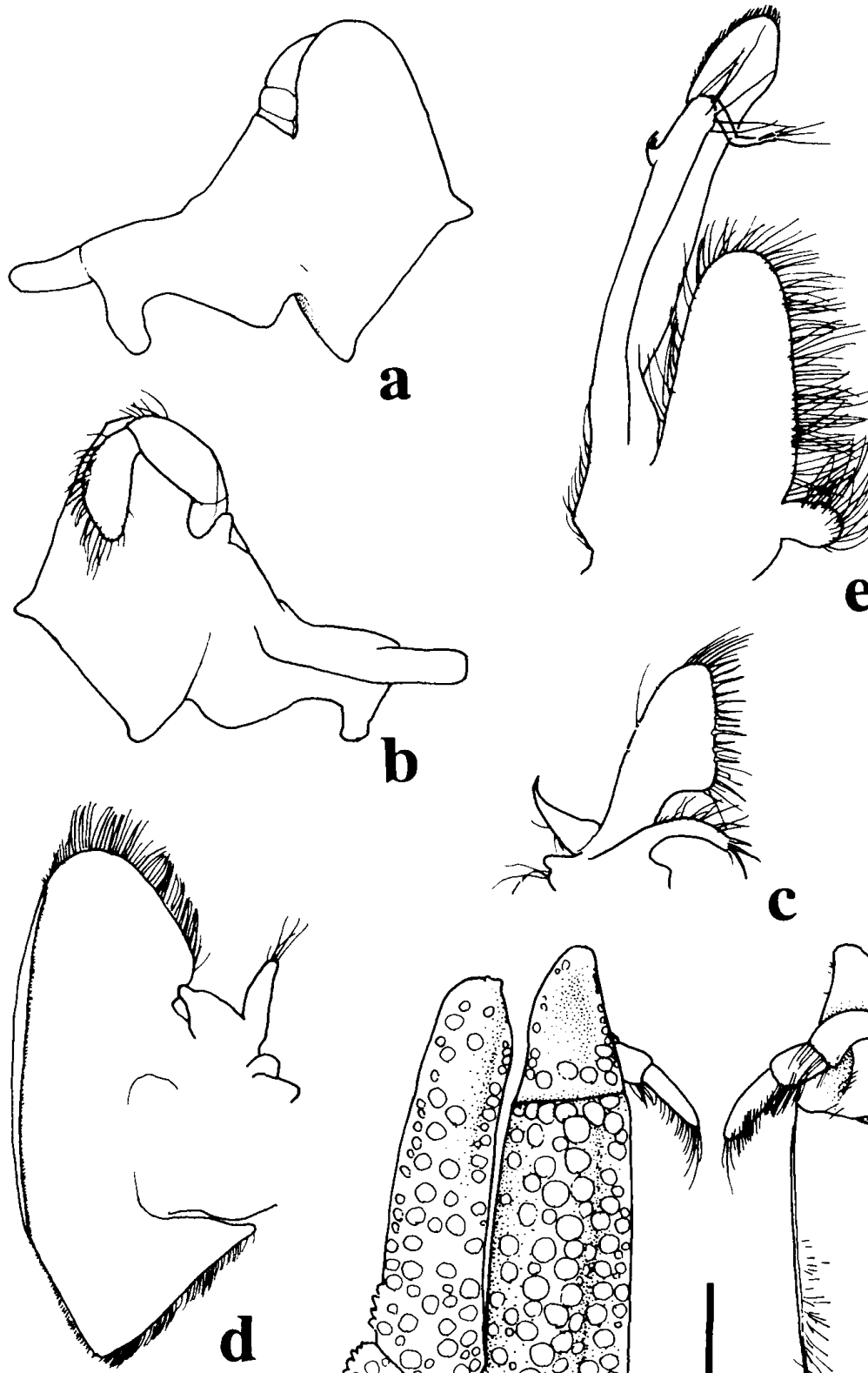

C

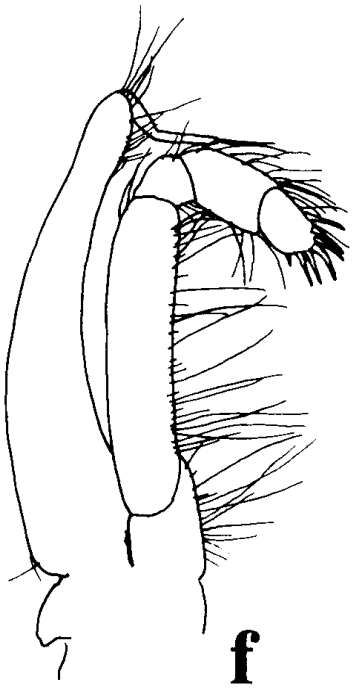

\section{c}
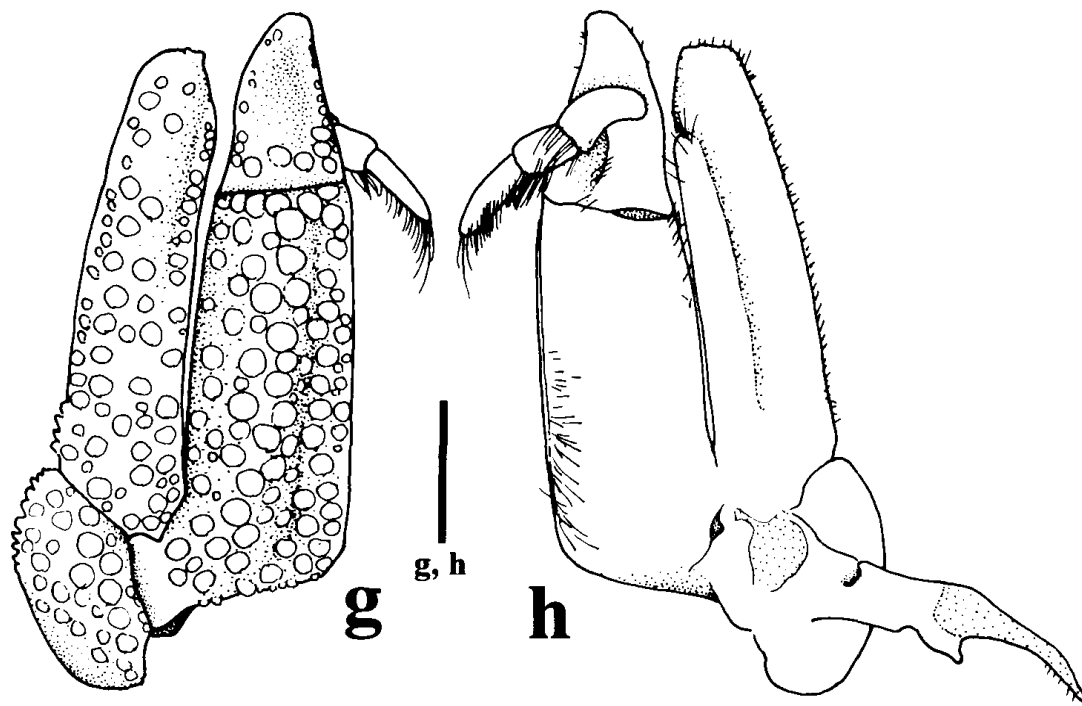

Fig. 4. Raylilia intermedia n. sp., holotype, ơ $(9.7 \times 9.0)$, NSMT-Cr 15813. a, Mandible, external view; b, same, internal view; c, maxillule, external view; d, maxilla, external view; e, first maxilliped, external view; f, second maxilliped, external view; g, third maxilliped, external view; h, same, internal view. Scales: $1 \mathrm{~mm}$. 
gently convex in lateral 0.6 ; merus moderately bent dorsally in situ, about 0.6 times as long as ischium along mesial margin, shallowly concave medially; dactylus with distally denticulate setae along inner margin; exopod relatively narrow, rounded at tip, shallowly sulcate submarginally along distal half of mesial margin, fringed with short plumose setae on outer margin; internal exopodal ridge prominent, with several short setae; epipod reduced, not well calcified; podobranch absent. male.

Cheliped lost; coxal condyle subquadrate in male, longitudinally ovate in fe-

Ambulatory legs (Fig. 3c) slender, similar in shape, gradually decreasing in length from first to fourth, covered with minute, flat granules; coxal condyles rounded in male (Fig. 3d), small and rounded in female; meri, carpi, and propodi subcylindrical; dactyli subconical, with smooth dactylo-propodal locks on proximal ends of dorsal surfaces, fringed with very short setae along inner and outer margins.

Male thoracic sternites (Fig. 3d) covered with vesicular granules of various sizes; first to fourth sternites fused together; episternites not divided; abdominal cavity reaching to border between second and third sternites; median fissure reaching to border between seventh and eighth sternites. Female thoracic sternites covered with vesicular granules of various sizes; first to fourth sternites fused together; abdominal cavity reaching to border between second and third sternites.

Male abdomen (Fig. 3e) covered with vesicular granules of various sizes; first and second segments short, transversely subrectangular; main fused section composed of third to sixth segments, elongate trapezoidal, with triangular tooth just near distal margin; telson tongue-shaped, fringed with very short setae. Female abdomen (Fig. 3f) covered with vesicular granules of various sizes; first segment very short, transversely subrectangular; second and third segments short, transversely subrectangular; main fused section composed of fourth to sixth segments, ovate, moderately convex ventrally; telson tongue-shaped, fringed with very short setae.

Male first pleopod (Fig. 3g) translucent in distal 0.4; basal stalk stout, somewhat compressed, fringed with plumose setae along lateral margin; disto-lateral appendix slender, rounded at tip, furnished with short, plumose setae; distal lobe (Fig. 3h) devided into 3 triangular lobes, with oblique lateral plication and rounded mesio-proximal lobe. Male second pleopod (Fig. 3i) short, about 0.4 times as long as first pleopod, filiform, 2-segmented; basal part fringed with plumose setae; distal segment triangular.

Remarks. Raylilia intermedia has an intermediate appearance between $R$. coniculifera Galil, 2001 and R. mirabilis (cf. Zarenkov 1969; Galil 2001a). However, $R$. intermedia can be distinguished from $R$. coniculifera by the inconspicuous first tubercle on the epibranchial margin of carapace (distinct in $R$. coniculifera) and the trilobate distal part of the male first pleopod with a small, rounded process on the proximo-mesial part (undivided and lacking any process in $R$. coniculifera). Raylilia intermedia can be distinguished from $R$. mirabilis by the distinct V-shaped notch at mesial 0.3 of the anterior margin of the afferent channel (no such notch in $R$. mirabilis) and the division of the distal lobe of the male first pleopod into three triangular lobes (versus three tongue-shaped lobes separated by deep notches in $R$. mirabilis).

In addition, $R$. mirabilis, which is hitherto known from South China Sea, Philippines, New Caledonia, and Torres Strait (see Galil 2001a), is recorded here 
from Japanese waters for the first time.

Etymology. The specific name is from the Latin, intermedia (=intermediate), alluding to the crab's intermediate appearance between $R$. coniculifera and $R$. mirabilis.

Distribution. Known only from Philippines (type locality). Exact depth unknown.

Tanaoa yokoyai (Sakai, 1965), n. comb.

(Figs $1 \mathrm{~F}, 2 \mathrm{~d}-\mathrm{f}$ )

Ebalia tuberculata Yokoya, 1933: 121, fig. 41. [Preoccupied by E. tuberculata Miers, 1881]

Ebalia yokoyai Sakai, 1965: 27 [new name for E. tuberculata Yokoya, 1933], 1976: 74, pl. 24 (1).

Material examined. NSMT-Cr 15816, 1 o (14.8×11.1), Feb. 2003.

Additional description. Male first pleopod (Fig. 2d) slender, subcylindrical, almost straight; lateral margin fringed with short, plumose setae; distal part (Fig. 2e) compressed, with spinulate setae on internal surface medially. Male second pleopod (Fig. 2f) short, about 0.4 times as long as first pleopod; basal part roundly expanded, fringed with short, plumose setae; tip elongate tongue-shaped, with pointed apex.

Remarks. This species was originally described as Ebalia tuberculata by Yokoya (1933) and later renamed E. yokoyai by Sakai (1965) because of a nomenclatural reason. However, it should be referred to the genus Tanaoa, one of four new genera established by Galil (2003) for the members of the genus Randallia Stimpson, 1857, displaying five of six diagnostic characters of Tanaoa. Although the male first pleopod of this species does not have a preapical process, this character is supposedly variable within the genus. It is therefore concluded that this species is transferred to the genus Tanaoa as T. yokoyai (Sakai 1965).

Sakai (1976) mentioned that Ebalia yokoyai Sakai, 1965 resembles Arcania gracilipes Bell, 1855, which is now known as a species of the genus Raylilia, a new genus established by Galil (2001a), in the arrangement of the tubercles of the carapace. But it is apparent that they are quite different from each other in the form of the cheliped and first male pleopod (see Galil 2001a, figs 3, 4). Tanaoa yokoyai shows an affinity with $T$. pustulosa (Wood-Mason in Wood-Mason and Alcock 1891) in the tuberculated upper surface of the carapace, the arrangement of 10 tubercles on the lateral margin of the carapace, the separate basis of the third maxiliped, the elongate male telson, and the simply subcylindrical male first pleopod (see Chen 1989, fig. 15e). This species can be, however, distinguished from $T$. pustulosa by the absence of both the intestinal spine and the preapical process of the male first pleopod.

Distribution. This species has been known previously only from Japan, with bathymetric records of $100-400 \mathrm{~m}$ at sand or sandy mud bottom (Yokoya 1933; Sakai 
1965, 1976), but its geographic distribution was extended southwards to the Philippines by the present record.

Tokoyo trilobata $\mathrm{n}$. sp.

(Figs 5, 6, 7a-c, g, 8C, D)

Type series. Holotype: NSMT-Cr 15818, o (21.1×22.0), Mar. 1999. Paratypes: NSMT-Cr 15819, 2 o o $(16.4 \times 17.1,16.3 \times 17.2), 1$ ovig. $9(23.6 \times 24.9), 1$ 우 $(17.4 \times 19.0)$, Feb. 2003; NMCR 18009, 3 के के, 1 ㅇ $(18.0 \times 17.0-19.0 \times 18.0)$, Feb. 2003.

Comparative material examined. Tokoyo eburnea (Alcock, 1896): NSMT-Cr

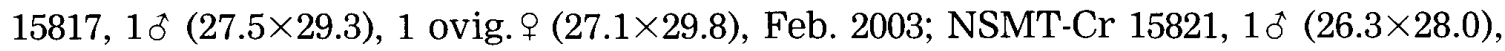

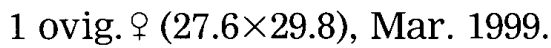

Description. Carapace (Figs 5a, 8C, D) subglobular, 1.0-1.1 times broader than long (1.04 times in holotype); regions ill-defined; upper surface entirely covered with microscopic flat granules. Frontal region produced on both angles, medially concave; margin divided into 2 lobes by small median notch. Orbit with 2 straight fissures on dorsal roof and elongate V-shaped fissure on infraorbital margin, fringed with relatively long setae along entire margin. Branchial margin with small, rounded median tooth. Intestinal region sometimes weakly divided by pair of shallow, longitudinal grooves. Posterior margin (Fig. 7g) divided into 3 rounded lobes, median lobe somewhat smaller than lateral lobes.

Ocular peduncle short, completely set in orbit when retracted; dorsal extension onto cornea subrectangular with rounded tip. Antennule obliquely folded into fossa; basal segment occupying ventral 0.6 of fossa, fringed with short setae along upper margin. Antenna with transversely ovate basal segment; second segment subcylindrical, movable, placed in orbital hiatus. Afferent channel with large Vshaped notch near lateral angle of anterior margin.

Mandible (Fig. 6a, b) well calcified; cutting edge triangular in outline, pointed medially; endopod palp 3-segmented, fringed with short, stout setae on outer margin of terminal segment. Maxillule (Fig. 6c) with coxal endite somewhat compressed, directed mesially, with some stout terminal setae; basial endite triangular, with both stout and thin setae on mesial margin, fringed with some thin setae on lateral margin; endopod tongue-shaped, constricted distally, with tuft of plumose setae at base of lateral margin. Maxilla (Fig. 6d) with coxal endite missing; basial endite elongate tongue-shaped, fringed with short setae; endopod triangular, constricted in distal half; exopod (scaphognathite) longitudinally expanded into oval structure, entirely fringed with short, plumose setae. First maxilliped (Fig. 6e) with coxal endite semiglobular, densely setose; basial endite lobular, expanded into triangular structure, with sparse, short setae on external surface, densely fringed with moderately long setae along mesial margin and short, plumose setae along lateral margin; endopod lobular, longitudinally expanded, rounded at apex, fitting into efferent channel, fringed with short setae along mesial margin and lateral half of apex, plicate on external surface, fringed with very short setae along plication; exopod longitudinally filiform, with moderately long, plumose setae around tip, bearing flagellum with some plumose terminal setae. Second maxilliped (Fig. 6f) with submarginal row of plumose setae along mesial margin of ischium and merus, and with fringe of long, plumose setae along mesial 


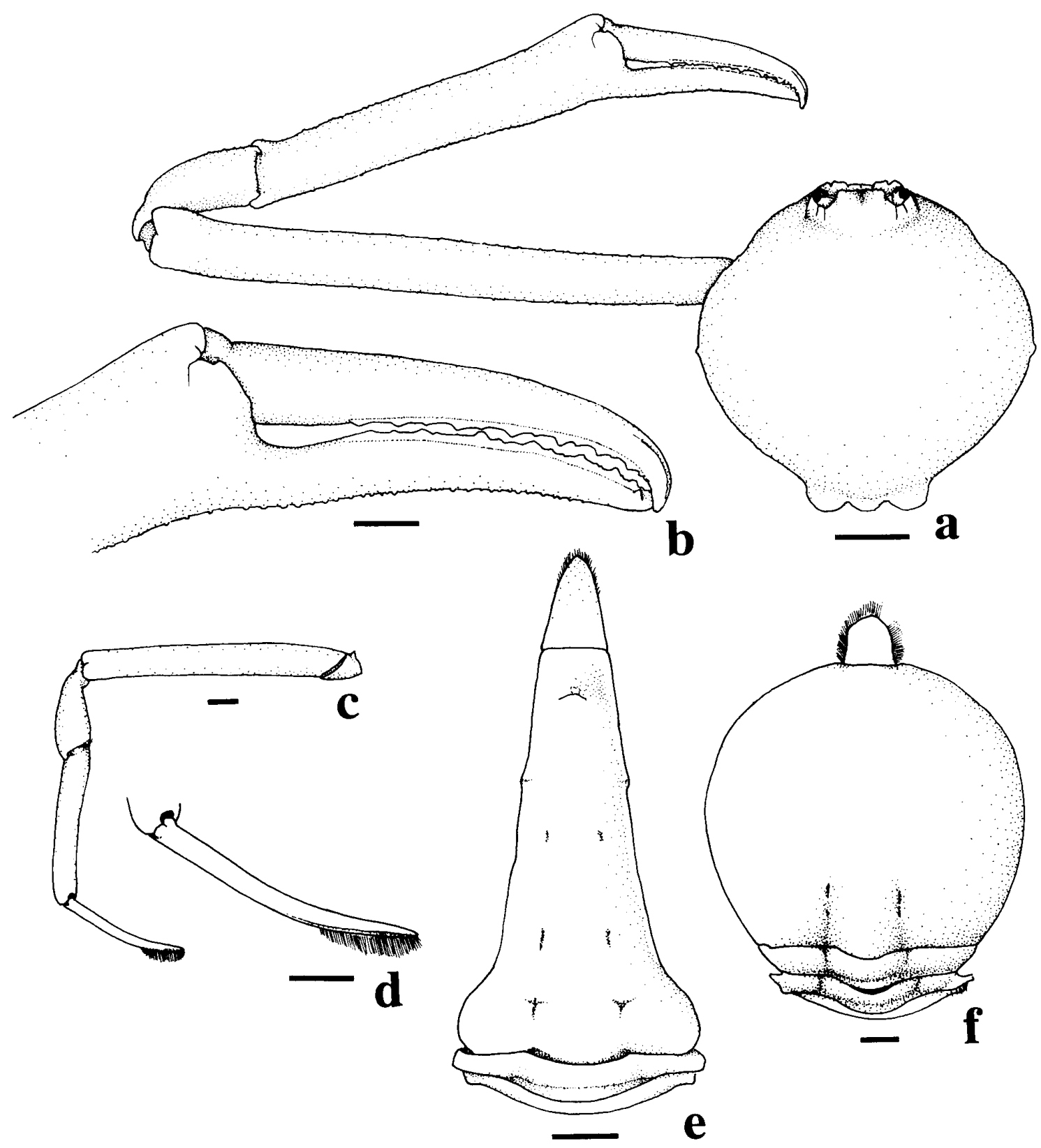

Fig. 5. Tokoyo trilobata n. sp., holotype, o (21.1×22.0), NSMT-Cr 15818 (a-e) and paratype, ovig. ㅇ (23.6×24.9), NSMT-Cr 15819 (f). a, Carapace and left cheliped, dorsal view; b, left chela, dorsal view; c, left second ambulatory leg, dorsal view; d, dactylus of same, dorsal view; e, male abdomen, ventral view; $\mathrm{f}$, female abdomen, ventral view. Scales: $5 \mathrm{~mm}$ for a; $2 \mathrm{~mm}$ for b-f.

margin; propodus densely fringed with setae along outer and distal margin; dactylus armed with stout setae around tip; exopod filiform, tapering distally, fringed with short, plumose setae along proximal half and distal 0.1 of lateral margin, bearing flagellum with some plumose terminal setae; exite rounded, fringed with short, plumose setae.

Third maxilliped (Fig. 6g, h) covered with microscopic flat granules; basis 


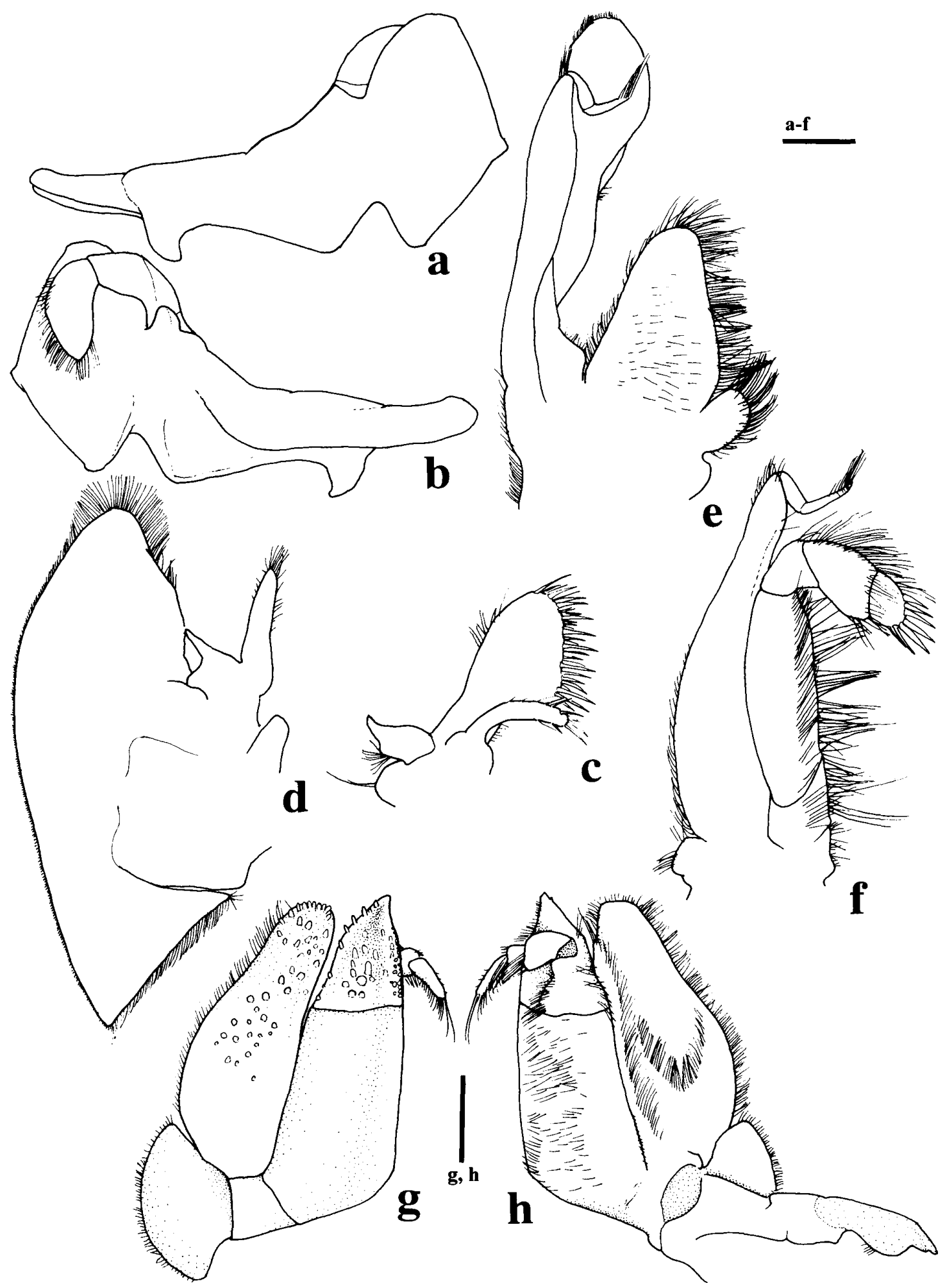

Fig. 6. Tokoyo trilobata $n$. sp., holotype, o (21.1 $\times 22.0)$, NSMT-Cr 15818. a, Mandible, external view; b, same, internal view; c, maxillule, external view; d, maxilla, external view; e, first maxilliped, external view; f, second maxilliped, external view; g, third maxilliped, external view; $h$, same, internal view. Scales: $1 \mathrm{~mm}$ for a-f; $2 \mathrm{~mm}$ for $\mathrm{g}-\mathrm{h}$. 

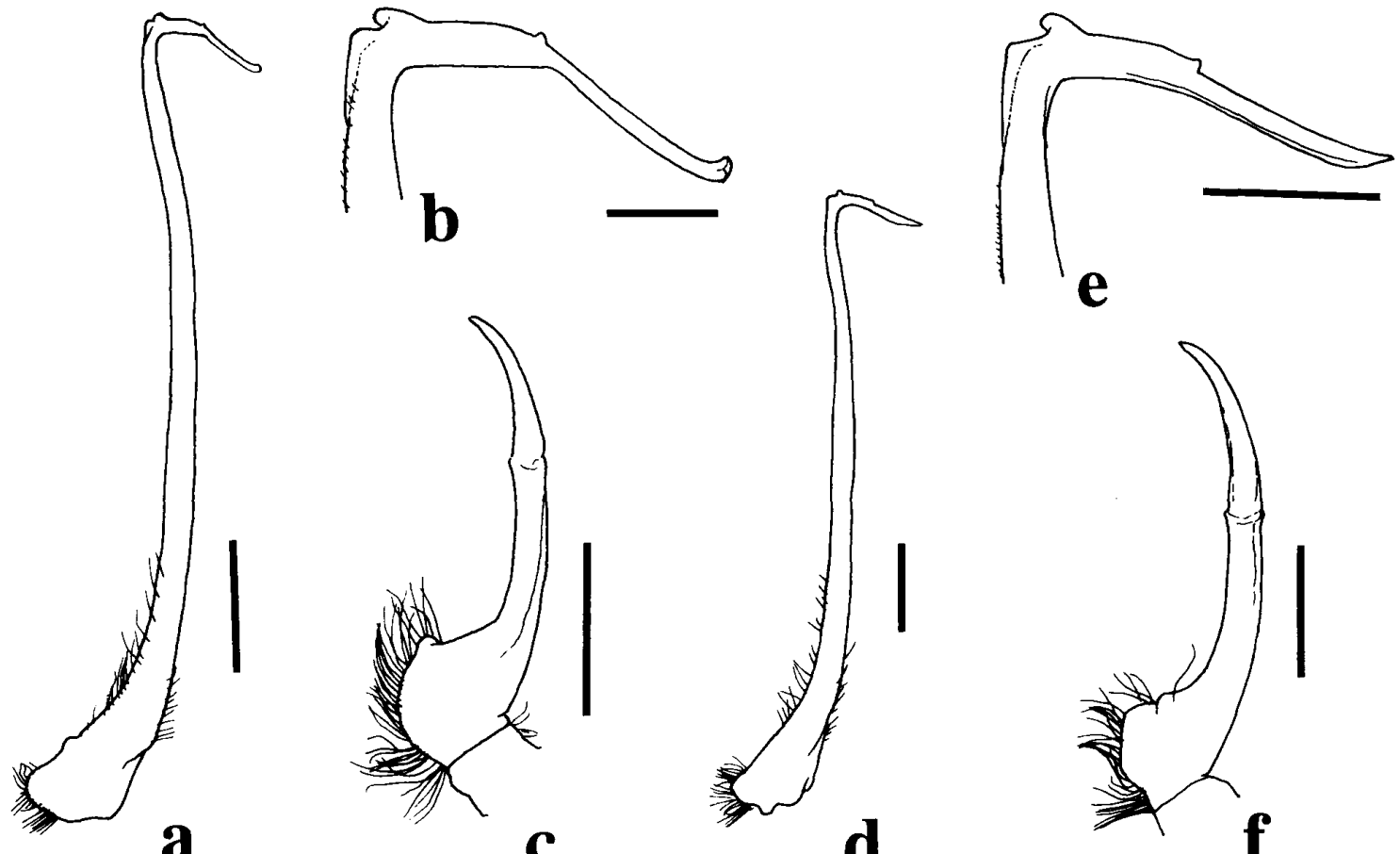

$\mathbf{a}$
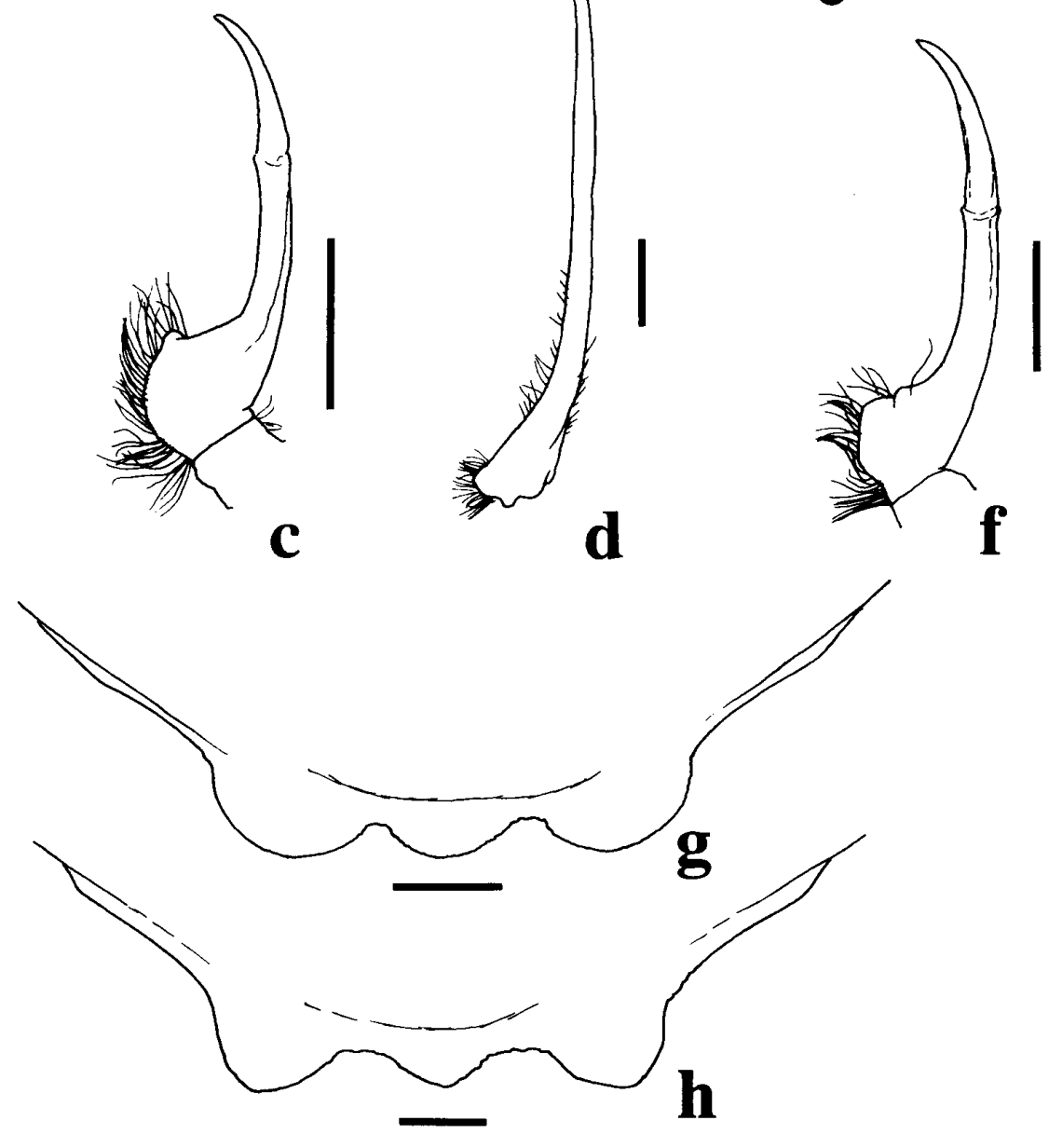

d

$\mathbf{f}$

Fig. 7. Tokoyo trilobata $\mathrm{n}$. sp., holotype, o $(21.1 \times 22.0)$, NSMT-Cr $15818(\mathrm{a}-\mathrm{c}, \mathrm{g})$ and Tokoyo eburnea (Alcock, 1896), o (26.3×28.0), NSMT-Cr 15817 (d-f, h). a, d, Right male first pleopods, external view; $b$, e, distal parts of same, external view; $c, f$, male second pleopods, external view; g, h, posterior lobes of carapace, dorsal view. Scales: $2 \mathrm{~mm}$ for a, $d, g, h ; 1 \mathrm{~mm}$ for $\mathrm{c}$, e, f; $0.5 \mathrm{~mm}$ for $\mathrm{b}$.

fused with ischium, but separated by fissure on internal and external surfaces; ischium longitudinally convex in lateral 0.6 , with submarginal row of short setae along mesial margin in female; merus gently bent dorsally in situ, about 0.8 times as long as ischium along mesial margin, sparsely covered with conical granules; dactylus with distally denticulate setae along inner margin; exopod subsquamate, rounded at tip, sparsely covered with acute granules on distal 0.7 , moderately arcuate and fringed with short, plumose setae on lateral margin; internal exopodal ridge prominent, with short setae; epipod reduced, not calcified; podobranch ab- 
sent.

Cheliped (Fig. 5a) slender, elongate, 3.4-4.0 times as long as carapace in male $(n=5 ; 4.0$ times in holotype), 2.8 3.0 times in female $(n=2)$, sparsely covered with microscopic pearly granules; coxal condyle subquadrate in male, subrectangular in female; merus cylindrical; carpus short; palm subcylindrical, slightly dilated distally; fingers leaving gap along proximal 0.3 in large male, entirely meeting in others, crossed at tip; movable finger 0.6-0.7 times as long as palm measured along outer margin in male $(n=5 ; 0.59$ times in holotype), 0.7-0.8 times in female $(n=2)$; immovable finger armed with small, triangular tooth just near distal end so as to fit with tip of movable finger (Fig. 5b); cutting edges armed with several triangular teeth.

Ambulatory legs (Fig. 5c) slender, smooth, similar in shape, gradually decreasing in length from first to fourth; coxal condyles rounded in male, concealed beneath sternites in female; meri, carpi, and propodi subcylindrical; dactyli (Fig. 5d) subconical, with acute tip, fringed with dense, short setae along distal 0.3 of outer margin in first to third legs, along distal 0.5 in fourth leg.

Male thoracic sternites entirely covered with microscopic flat granules; third sternite divided from fourth sternite by medially interrupted, transverse groove; median suture present, reaching to border between seventh and eighth sternites;

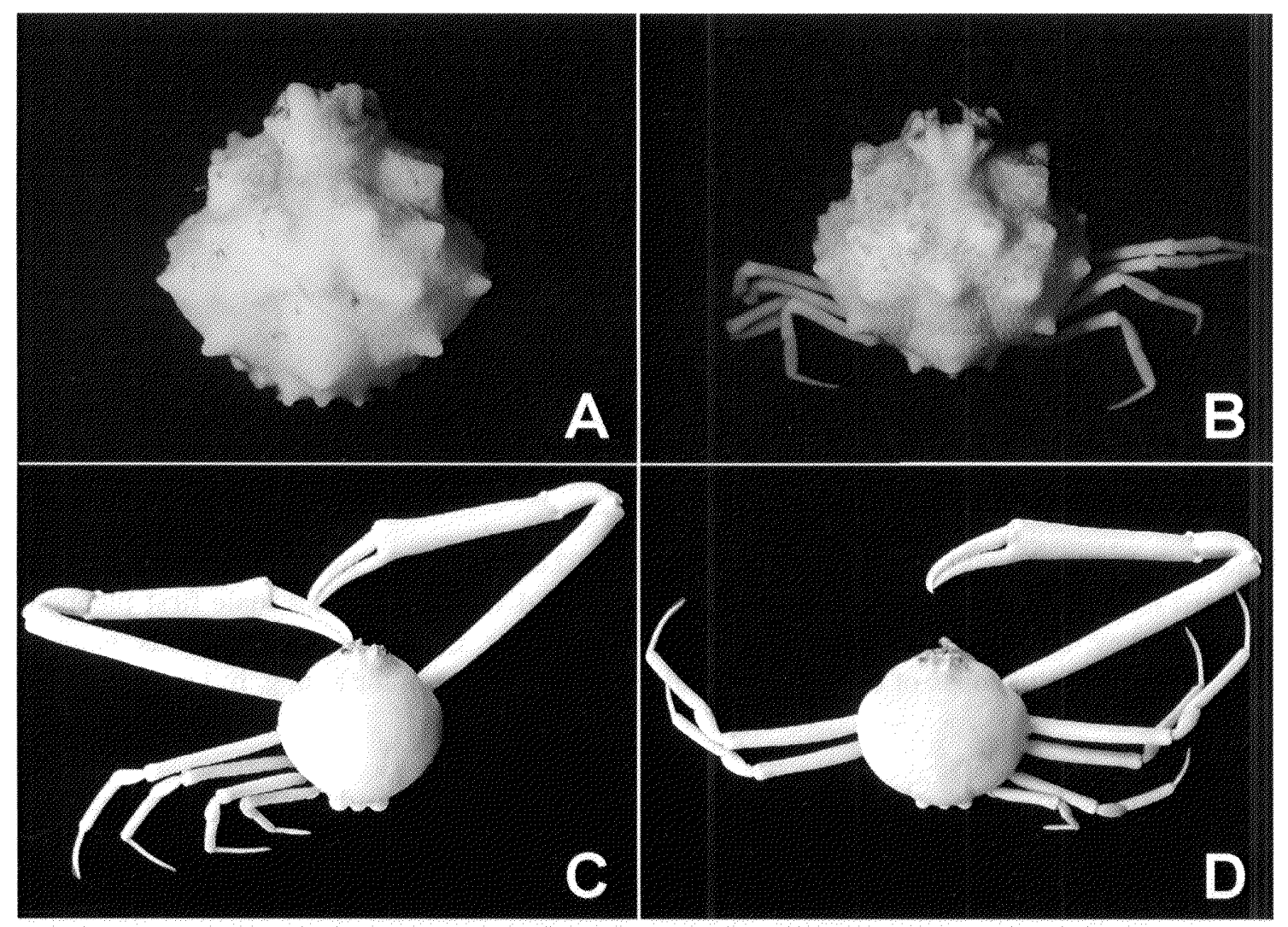

Fig. 8. Leucosiid crabs from Balicasag Island, Bohol, Philippines (specimens in alcohol). A, B, Raylilia intermedia n. sp., holotype, o (9.7 $\times 9.0)$, NSMT-Cr 15813 (A) and paratype, ovig. 9 $(13.0 \times 13.7)$, NSMT-Cr 15814 (B); C, Tokoyo trilobata n. sp., holotype, $\delta(21.1 \times 22.0)$, NSMT-Cr 15818; D, Tokoyo eburnea (Alcock, 1896), of (27.5×29.3), NSMT-Cr 15817. 
episternites incompletely divided by shallow grooves; abdominal cavity reaching to border between second and third sternites. Female thoracic sternites entirely covered with microscopic flat granules; third sternite divided from fourth sternite by medially interrupted transverse groove; sixth sternite with longitudinally ovate vulvae; abdominal cavity reaching to buccal cavern.

Male abdomen (Fig. 5e) entirely covered with microscopic flat granules; first segment very short, transversely rectangular, bent proximally; second segment short, roundly convex on proximal margin; main fused section composed of third to sixth segments, elongate trapezoidal, fringed with very short setae along lateral margin; sixth segment sometimes divided by remnant suture (undivided in holotype), with triangular median tooth. Telson elongate triangular with rounded tip, fringed with very short setae. Female abdomen (Fig. 5f) seemingly smooth but entirely covered with microscopic flat granules; first segment very short, transversely subrectangular; second and third segment short, transversely subrectangular, medially convex ventrally; main fused section composed of fourth to sixth segments, ovoid, weakly convex ventrally, with pair of shallow, longitudinal grooves along proximal $0.3-0.5$ of midline. Telson tongue-shaped with weakly pointed tip, densely fringed with short setae.

Male first pleopod (Fig. 7a) slender, fringed with short plumose setae along proximal 0.3 of lateral margin; distal part (Fig. 7b) directed medially at right angle, with triangular process on lateral corner; tip spatulate, rounded. Male second pleopod (Fig. 7c) short, filiform, 2-segmented; basal part fringed with plumose setae; distal segment elongate triangular, weakly curled laterally.

Remarks. Tokoyo trilobata is closely similar to $T$. eburnea, and the two species may have been confused with each other. However, T. trilobata can be distinguished from $T$. eburnea by two main characters. The posterior margin of the carapace is divided into three rounded lobes in T. trilobata (Fig. $7 \mathrm{~g}$ ), while in $T$. eburnea the lobes of posterior margin are subtriangular, leaving a short space between the median lobe and each lateral lobe (Fig. 7h). Also, the tip of the male first pleopod is rounded in T. trilobata (Fig. 7b), but acute in T. eburnea (Fig. 7e). Tokoyo trilobata is more abundant than T. eburnea at Balicasag Island, but generally smaller than T. eburnea in size (cf. Galil 2003).

Etymology. The specific name is a combination of the Latin, tri (=three) and lobatus (=lobed), in reference to the trilobate posterior margin of the carapace.

Distribution. Known only from Philippines (type locality). Exact depth unknown.

\section{Acknowledgments}

We wish to express our cordial thanks to Mr. Paterno A. Comintan of the National Museum of the Philippines for his invaluable help during the first and third authors' visit, and also to Dr. Tomoki Kase of the National Science Museum, Tokyo, and Dr. Tomoyuki Komai of the Natural History Museum and Institute, Chiba, for making available the specimens for this study. We are indebted to Drs Paul F. Clark and Bella S. Galil for their improving and critical reading of the manuscript. 


\section{References}

Balss, H. 1922. Ostasiatische Decapoden. III. Die Dromiaceen, Oxystomen und Parthenopiden. Archiv für Naturgeschichte (A) 88: 104-140.

Bennett, E. W. 1964. The marine fauna of New Zealand: Crustacea Brachyura. New Zealand Department of Scientific and Industrial Research 153: 1-120.

Chen, H. 1989. Leucosiidae (Crustacea, Brachyura). In: Forest, J. (Ed.) Résultats des campagnes Musorstom, vol. 5. Mémoirs du Muséum National d'Histoire Naturelle (A) 144: 181-263.

Chen, H. and Sun, H. 2002. Arthropoda Crustacea Brachyura marine primitive crabs. Fauna Sinica Invertebrata 30: i-xiii+1-597, pls 1-16.

Dai, A. and Yang, S. 1991. Crabs of the China Seas. China Ocean Press, Beijing, 682 pp.

Dell, R. K. 1968. Notes on New Zealand crabs. Records of the Dominion Museum 6: 13-28.

Galil, B. S. 2001a. A new genus and species of leucosiid crab (Crustacea, Decapoda, Brachyura) from the Indo-Pacific Ocean. Zoosystema 23: 65-75.

Galil, B. S. 2001b. A revision of the genus Arcania Leach, 1817 (Crustacea: Decapoda: Leucosioidea). Zoologische Mededelingen 75: 169-206.

Galil, B. S. 2001c. A revision of the genus Myra Leach, 1817 (Crustacea: Decapoda: Leucosioidea). Zoologische Mededelingen 75: 409-446.

Galil, B. S. 2003. Four new genera of leucosiid crabs (Crustacea: Brachyura: Leucosiidae) for three new species and nine species previously in the genus Randallia Stimpson, 1857, with a redescription of the type species, $R$. ornata (Randall, 1939). Proceedings of the Biological Society of Washington 116: 395-422.

Hale, H. M. 1927. The Crustaceans of South Australia. Part I. Harrison Weir, Government Printer, Adelaide, $202 \mathrm{pp}$.

Herbst, J. F. W. 1783. Versuch einer Naturgeschichte der Krabben und Krebse nebst einer systematischen Beschreibung ihrer verschiedenen Arten. Vol. 1, Part 2-5, pp. 87-182, pls 2-9.

Ihle, J. E. W. 1918. Die Decapoda Brachyura der Siboga-Expedition. III. Oxystomata: Calappidae, Leucosiidae, Raninidae. Siboga-Expeditie Monographie 39b: 159-322.

Kim, H. S. 1973. Illustrated Encyclopedia of Fauna and Flora of Korea, Volume 14. Anomura and Brachyura. Samhwa Publishing, Seoul, 694 pp. [In Korean]

Miers, E. J. 1886. Report on the Brachyura collected by H.M.S. Challenger during the years 1873-76. Report on the Scientific Results of the Voyage of H.M.S. Challenger during the Years 1873-76, under the Command of Captain George S. Nares, R.N., F.R.S. and the Late Captain Frank Tourle Thomson, R.N., Zoology 17 (2): i-1+1-362, pls 1-29.

Milne-Edwards, A. 1873. Description de quelques Crustacés nouveaux ou peu connus provenant du Musée de M. C. Godeffroy. Journal des Museums Godeffroy 1 (4): 77-88, pls 1,2 .

Rathbun, M. J. 1923. Report on the crabs obtained by the F.I.S. "Endeavour" on the coasts of Queensland, New South Wales, Victoria, South Australia and Tasmania. Report on the Brachyrhyncha, Oxystomata and Dromiacea. Biological Results of the Fishing Experiments Carried out by the F.I.S. "Endeavour" 1904-14, 5: 95-156, pls 16-42.

Sakai, T. 1937. Studies on the crabs of Japan. II. Oxystomata. Science Reports of the Tokyo Bunrika Daigaku (B) 3 (Supplement): 67-192, pls 10-19.

Sakai, T. 1965. The Crabs of Sagami Bay Collected by His Majesty, the Emperor of Japan. Maruzen, Tokyo, xvi $+206+92+32$ pp., 100 pls, 1 map.

Sakai, T. 1976. Crabs of Japan and the Adjacent Seas. Kodansha, Tokyo, xxix +773 pp., 3 maps [English volume]; $461 \mathrm{pp}$. [Japanese volume]; $16 \mathrm{pp} ., 251 \mathrm{pls}$ [plate volume]. 
Takeda, M. 1977. Crabs of the Ogasawara Islands, V. A collection made by dredging. Memoirs of the National Science Museum (10): 113-140, pls 12-17.

Takeda, M. and Miyake, S. 1970. Crabs from the East China Sea, IV. Gymnopleura, Dromiacea and Oxystomata. Journal of the Faculty of Agriculture, Kyushu University 16: 193-235, pl. 1.

Takeda, M. and Miyake, S. 1972. Crabs from the East China Sea, V. A remaining collection. Occasional Papers of Zoological Laboratory, Faculty of Agriculture, Kyushu University 3: $63-90$, pl. 3.

Takeda, M. and Tachikawa, H. 1995. Crabs of the Ogasawara Islands. VIII. Two species of the family Leucosiidae. Bulletin of the National Science Museum, Tokyo (A) 21: 211-218.

Tyndale-Biscoe, M. and George, R. W. 1962. The Oxystomata and Gymnopleura (Crustacea, Brachyura) of Western Australia with descriptions of two new species from Western Australia and one from India. Journal of the Royal Society of Western Australia 45 (3): 65-96.

Whitelegge, T. 1900. Crustacea, Part I. Decapoda and Stomatopoda. In: Scientific results of the trawling expedition of H.M.C.S. "Thetis", off the coast of New South Wales, in February and March, 1898. Part 2. Australian Museum Memoir 4: 133-199, pls. 32-35.

Yokoya, Y. 1933. On the distribution of Decapoda crustaceans inhabiting the continental shelf around Japan, chiefly based upon the materials collected by S. S. Soyo-Maru, during the years 1923-1930. Journal of the College of Agriculture, Tokyo Imperial University 12: 1-225.

Zarenkov, N. A. 1969. [Crabs of the family Leucosiidae (subfamilies Ebaliinae and Iliinae) collected in tropical waters of the Indian and the Pacific Ocean]. Nauchnye Doklady Vysshei Shkoly, Biologicheskie Nauki 1969 (10): 16-26. [In Russian]

Zarenkov, N. A. 1990. Crabs of the family Leucosiidae (subfamilies Philyrinae and Leucosiinae) collected in tropical waters of the Pacific and Indian oceans. Nauchnye Doklady Vysshei Shkoly, Biologicheskie Nauki 1990 (1): 52-70. [In Russian with English abstract] 